\title{
Development of a new, sensitive, and robust analytical and bio-analytical RP- HPLC method for in-vitro and in-vivo quantification of naringenin in polymeric nanocarriers
}

\author{
Ranjana Bhandari, Astha Kuhad, Jyoti Kumar Paliwal and Anurag Kuhad ${ }^{*}$
}

\begin{abstract}
Background: Naringenin is a flavanone having strong antioxidant potential. It is an anti-hyperlipidemic, antidepressant, anti-cancer, and neuroprotective agent. However, its major limitation is its low oral bioavailability.

Objective: In order to overcome this limitation and to explore its antioxidant potential in autism spectrum disorders, we developed brain targeting PLGA nanocarriers of naringenin. Current study involves development of a sensitive and robust RP-HPLC method for detection and quantification (in vitro and in vivo) of naringenin in nanoparticles.

Methods: An isocratic RP-HPLC method was developed using $C_{18}$ reversed-phase column $(250 \times 4.6 \mathrm{~mm}$ internal diameter and $5 \mu \mathrm{m}$ particle size). Flow rate of mobile phase was $1 \mathrm{ml} / \mathrm{min}$ and temperature of column was $30{ }^{\circ} \mathrm{C}$. Methanol and $0.5 \%$ ortho-phosphoric acid in MilliQ water (pH 2) (70:30) was used as mobile phase. The ultraviolet detection wavelength for quantification was at $289 \mathrm{~nm}$.
\end{abstract}

Results: Calibration curve showed linearity within the concentration range from 0.5 to $40 \mu \mathrm{g} / \mathrm{ml}\left(R^{2}=1\right)$ for the analytical method and for plasma $\left(6.3-200 \mathrm{ng} / \mathrm{ml}\left(R^{2}=0.9975\right)\right)$ and brain tissue samples $(31.25-12,500 \mathrm{ng} /$ $\mathrm{ml}\left(R^{2}=1\right)$ ). Limit of detection (LOD) and limit of quantification (LOQ) were $0.15 \mu \mathrm{g} / \mathrm{ml}$ and $0.44 \mu \mathrm{g} / \mathrm{ml}$ for the analytical method. For bio-analytical method, LOD and LOQ were $9.71 \mathrm{ng} / \mathrm{ml}$ and $29.44 \mathrm{ng} / \mathrm{ml}$ for plasma and $9.06 \mathrm{ng} / \mathrm{ml}$ and $27.44 \mathrm{ng} / \mathrm{ml}$ for brain sample. Both the method was precise, accurate, and robust. Bioanalytical method showed good recovery from plasma and brain samples (> 95\%).

Conclusion: This analytical and bio-analytical method was applied to detect entrapment efficiency, in-vitro release, and pharmacokinetic parameters of naringenin nanoparticles.

Keywords: Brain, Naringenin, Plasma, PLGA nanoparticles, RP-HPLC

\footnotetext{
* Correspondence: anurag_pu@yahoo.com

Pharmacology Research Laboratory, University Institute of Pharmaceutical

Sciences, UGC-Centre of Advanced Study, Panjab University, Chandigarh 160 014, India
} 


\section{Introduction}

$( \pm$ )-Naringenin (Fig. 1), a flavanone, is abundantly found in grapefruit as well as in oranges and tomato skin (Felgines et al. 2000; Vallverdu et al. 2012). Naringenin shows inhibition of CYP1A2 isoform of human cytochrome P450 metabolizing enzymes (Fuhr et al. 1993). Naringenin also exerts its antioxidant effect by reducing oxidative damage to DNA induced by the exposure to radiations in mice by inhibition of NF-kB pathway (Kumar and Tiku 2016). It shows its anti-hyperlipidemic effect by inhibiting the secretion of very low-density lipoproteins (VLDL) (Nahmias et al. 2008). It also exerts its anti-depressant effects in chronic unpredictable mild stress by BDNF signaling (Yi et al. 2014). As a result of its ability to hamper cell-proliferation by binding to estrogen receptors (ER), naringenin has anti-proliferative effects in breast cancer, colon cancer, uterus cancer cell (Birt et al. 2001). It has also been observed to have anti-estrogenic effects by the regulation of palmitoylation of estrogen receptor- $\alpha$. Its effects have been observed in osteoporosis, cancer as well as cardiovascular diseases (Galluzzo et al. 2008). Naringenin has a therapeutic role in the suppression of neuroinflammation by inducing the suppression of cytokine signaling 3 expression (SOCS)-3 in glial cells (Wu et al. 2016). It has shown neuroprotective effect in middle cerebral artery occlusion (MCAO) model of ischemic stroke via inhibition of NF-kB signaling (Raza et al. 2013). Despite its therapeutic potential, naringenin's role clinically has been hampered as a result of its low solubility resulting in poor bioavailability and considerable metabolism before entering into the systemic circulation (Ratnam et al. 2006; Yen et al. 2009). Hence, in order to enhance its bioavailability, it was decided to encapsulate it into nanoparticles which can cross the blood-brain barrier (BBB) and will specifically target brain (Badri et al. 2017; Kumari et al. 2010; Natarajan et al. 2017; Xue et al.
2015). We prepared naringenin-loaded poly (lactic-co-glycolic acid) (PLGA) nanoparticles and wanted to determine the content of naringenin in the nanoparticles by developing and validating a specific, fast, and suitable HPLC method which could be used for determining not only the content of naringenin in nanoparticles but also for in-vitro drug release studies. The method which we have developed here has been extrapolated for estimation of the drug in plasma and brain respectively for in-vivo pharmacokinetic studies as well as to quantify the brain uptake of naringenin by calculating the brain:plasma ratio of naringenin. Our prepared naringenin nanoparticles showed beneficial effect in attenuating oxidative stress, neuroinflammation, and mitochondrial dysfunction in the experimental paradigm of autism spectrum disorders (Bhandari et al. 2018). A number of methods have been reported in literature where naringenin has been quantified in several matrixes such as plasma, serum, urine, grapefruit juice using high-performance liquid chromatography (HPLC) (Fisher and Wheaton 1976; Gupta et al. 2012; Ishii et al. 1997; Peng et al. 1998; Ribeiro and Ribeiro 2008). There are some other methods reported in literature by Dalagnol et al. (2013) and Cordenonsi et al. (2016) about naringenin. Method used by Dalagnol et al. (2013) varied from our method with respect to the calibration curve range $(0.1-15 \mu \mathrm{g} / \mathrm{ml})$, mobile phase composition (methanol:water) (60:40, $\mathrm{pH} 2.5)$, and that their method was for quantification of naringenin in lecithin/chitosan nano- and microparticle suspension. Cordenonsi et al. (2016) used shorter column of length $150 \mathrm{~mm}$, gradient mode for separation, and their mobile phase composition was (ACN:water, $\mathrm{pH} 4$ ) for the determination of both naringin and naringenin in Eudragit nanoparticles. Methods in both of the above studies had different limit of quantification (LOQ) and limit of detection (LOD) as compared to our method, which were lower as

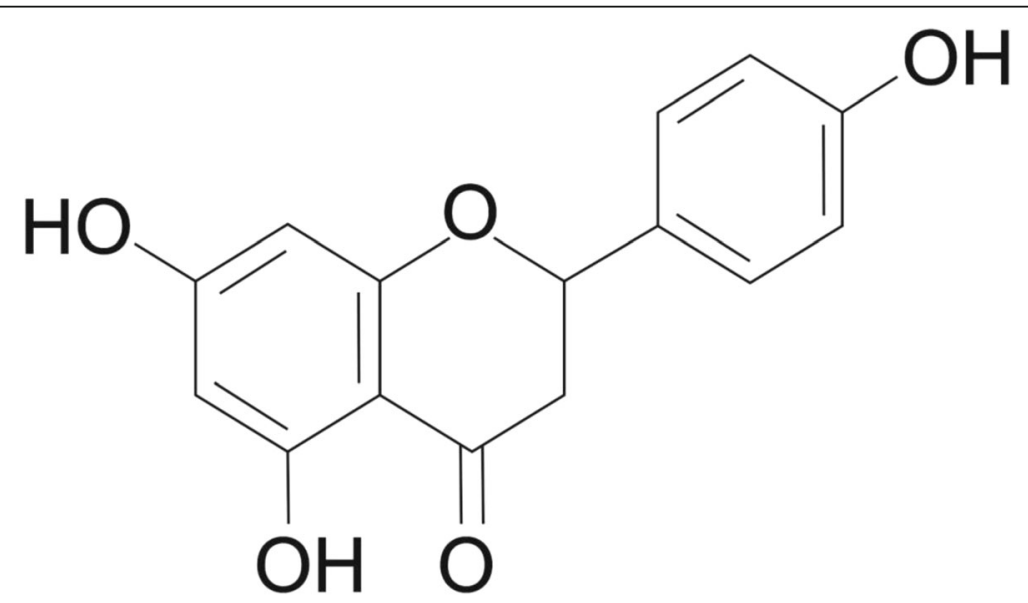

Fig. 1 Chemical structure of naringenin 
compared to Cordenonsi et al. (2016), and our method showed better resolution as we had used column of $250 \mathrm{~mm}$ in comparison to $150 \mathrm{~mm}$ column used by Cordenonsi et al. (2016). Longer column leads to greater number of theoretical plates leading to improved resolution. Our calibration curve range was also greater as compared to Dalagnol et al. (2013). Our developed method was an elementary, specific, precise, and rapid technique for quantification of naringenin in PLGA nanoparticles which could be successfully extrapolated to plasma and brain for the in vivo pharmacokinetic studies as well as to study the enhanced uptake of naringenin across the blood-brain barrier (BBB), after its encapsulation into nanoparticles.

The primary aim of this study was the buildup and verification of a rapid, productive, simple, robust, as well as economical reversed-phase high-performance liquid chromatography (RP-HPLC) method for in-vitro as well as in-vivo quantification of naringenin from PLGA nanoparticles.

\section{Material and methods Chemicals}

$( \pm$ )-Naringenin $\geq 95 \%$ was procured from Sigma Aldrich (St. Louis, MO, USA). Methanol and acetonitrile (HPLC grade) were obtained from Merck (Darmstadt, Germany). Ortho-phosphoric acid (analytical grade) was obtained from Fisher Scientific (Leicestershire, UK). Ultrapure water used for HPLC analysis was obtained from Milli-Q water purification system (Millipore, MA, USA). Analytical grade chemicals, as well as reagents, were used throughout the study. Then, $0.45 \mu \mathrm{m}$ solvent filter and $0.22 \mu \mathrm{m}$ nylon syringe filter (Millipore, MA, USA) respectively were also used.

\section{Equipment}

The analysis of naringenin was done using a Waters 2996 HPLC system with a Photo Diode Array (PDA) detector (Waters 2996), and the results were processed by Empower, Waters software. Chromatographic separations were done on a Waters ${ }^{\circ}$ analytical column, Sunfire, RP-18 (5 $\mu \mathrm{m}$ particle size, $250 \times 4.6 \mathrm{~mm}$ i.d.). A BS223S (Sartorius, USA) analytical balance, Cyberscan Eutech pH 510 (E. Merck, USA) pH meter, and an ultrasonicator were other equipments used.

\section{Chromatographic conditions}

Methanol and 0.5\% ortho-phosphoric acid in MilliQ water $(\mathrm{pH}$ 2.47) in the ratio of (70:30) were used as mobile phase. Ortho-phosphoric acid was used as HPLC mobile phase modifier and it was optimum as acid as it provides reasonable buffering at $\mathrm{pH} 2$ for LC-PDA applications (Jaenicke 1975). Each solvent was strained through $0.45 \mu \mathrm{m}$ nylon filter and used after degassing in an ultrasonic bath. Separation was performed using isocratic mode. The photodiode array detector (PDA) was set at 200-400 nm wavelength and the detection of chromatogram was at $289 \mathrm{~nm}$. The chromatographic analysis was executed at $30{ }^{\circ} \mathrm{C}$, with a flow rate of $1 \mathrm{ml} / \mathrm{min}$ and $20 \mu \mathrm{l}$ as the volume of injection. All the parameters of the method development were same for assessment of naringenin in plasma and brain except the mobile phase flow rate which was scaled down to $0.8 \mathrm{ml} / \mathrm{min}$ in order to reduce the slight peak tailing observed.

\section{Standard stock solution preparation}

Naringenin's stock solution $(100 \mu \mathrm{g} / \mathrm{ml})$ was formulated in methanol (HPLC grade). Dilutions ( $v: v)$ were prepared from above stock with methanol to obtain dilutions in the range of $40 \mu \mathrm{g} / \mathrm{ml}$ to $0.5 \mu \mathrm{g} / \mathrm{ml}$ for the analytical method validation. For the bio-analytical method, validation stock solutions of naringenin were also prepared in methanol $(1000 \mathrm{ng} / \mathrm{ml})$ for plasma and $(50 \mu \mathrm{g} / \mathrm{ml})$ for brain tissue samples and were diluted to obtain solutions in the range of $31.5-1000 \mathrm{ng} / \mathrm{ml}$ and $0.125-50 \mu \mathrm{g} / \mathrm{ml}$ respectively. These solutions were used for the various validation parameters, i.e., linearity, accuracy, precision, limit of detection (LOD), limit of quantification (LOQ), robustness, and system suitability by injecting $20 \mu \mathrm{l}$ into the column and the chromatograms were recorded.

\section{Method development and validation Method development}

The method was developed along with the above described chromatographic conditions. These conditions were selected after utilizing the possibility of different flow rate, varying the composition of mobile phase along with different ratios as well as $\mathrm{pH}$ of the mobile phase.

\section{Method validation}

The RP-HPLC method for naringenin was validated according to the $\mathrm{Q} 2 \mathrm{~B}(\mathrm{R} 1) \mathrm{ICH}$ guidelines for method validation (1996) and validated for linearity, LOD, LOQ, interday and intraday precisions, accuracy, reproducibility, recovery, robustness, and system suitability. The developed method was extrapolated to plasma and brain so that it could be used for pharmacokinetic studies and to quantify the brain-uptake of naringenin. The same method was also validated for linearity, intra- and inter-day precision, accuracy, as well as recovery in plasma and brain after processing the samples in order to study any changes due to matrix effect on the method (U.S. Department of Health and Human Services Food and Drug Administration, Bioanalytical Method Validation Guidance for Industry).

Linearity For determination of linearity, three repeated injections of standard solutions of naringenin at seven concentration levels within the range of $0.5 \mu \mathrm{g} / \mathrm{ml}$ to 
$40 \mu \mathrm{g} / \mathrm{ml}$ were injected into the system. Similarly, it was established by three repeated injections of rat plasma and brain tissue homogenate spiked with concentrations of $31.5-1000 \mathrm{ng} / \mathrm{ml}$ and $0.125-50 \mu \mathrm{g} / \mathrm{ml}$ respectively of naringenin leading to ultimate concentrations of 6.3$200 \mathrm{ng} / \mathrm{ml}$ for plasma and between 31.25 and 12,500 ng/ $\mathrm{ml}$ for brain samples respectively. A calibration plot of peak areas vs concentrations were used to determine linearity in all cases.

Limit of detection and limit of quantification The LOD and LOQ were used as a measure to detect sensitivity of the method in accordance with Guidance for Industry Q2B Validation of Analytical Procedures: Methodology (1996). LOQ and LOD of naringenin for the analytical as well as bio-analytical method were determined through the residual standard deviation obtained by linear regression analysis of the calibration curves. LOD and LOQ are calculated as follows:

LOD $=$ (residual standard deviation of the regression line/Slope of the calibration curve)*3.3

LOQ $=$ (residual standard deviation of the regression line/Slope of the calibration curve)*10

Accuracy To determine the accuracy of the analytical as well as bio-analytical procedure, quality control samples (QC) at three different concentrations of naringenin, i.e., $5 \mu \mathrm{g} / \mathrm{ml}, 20 \mu \mathrm{g} / \mathrm{ml}$, and $40 \mu \mathrm{g} / \mathrm{ml}$ for the analytical method while for the accuracy determination in plasma and brain samples concentrations were $200 \mathrm{ng} / \mathrm{ml}, 100 \mathrm{ng} / \mathrm{ml}$, and $50 \mathrm{ng} / \mathrm{ml}$ for plasma and 12,500 $\mathrm{ng} / \mathrm{ml}, 5000 \mu \mathrm{g} / \mathrm{ml}$, and
$250 \mathrm{ng} / \mathrm{ml}$ for brain samples respectively. These were within the range of calibration plot and were analyzed in triplicate $(n=3)$ with three injections of each concentration and were prepared from independent stock solutions. Assessment of accuracy had been done as the percentage accuracy and mean \% recovery. The percentage relative standard deviation (RSD) was also calculated.

Precision The precision of the analytical as well as bio-analytical procedure was evaluated by determination of inter-day and intra-day coefficient of variation. The percentage RSD was calculated as [SD (standard deviation) / mean] * 100. For the determination of the inter-day and the intra-day variation, $\mathrm{QC}$ at three different concentrations of naringenin $(5 \mu \mathrm{g} / \mathrm{ml}, 20 \mu \mathrm{g} / \mathrm{ml}$, and $40 \mu \mathrm{g} / \mathrm{ml})$ for the analytical method were used. For the precision determination in plasma and brain samples, concentrations were $200 \mathrm{ng} / \mathrm{ml}, 100 \mathrm{ng} / \mathrm{ml}$, and $50 \mathrm{ng} / \mathrm{ml}$ for plasma and $12,500 \mathrm{ng} / \mathrm{ml}, 5000 \mu \mathrm{g} / \mathrm{ml}$, and $250 \mathrm{ng} / \mathrm{ml}$ for brain samples respectively. These were within the range of calibration plot and were analyzed in triplicate $(n=3)$ with three injections of each concentration for three different days to study inter-day variation (for intermediate precision) and were analyzed at three different time points within the same day for intra-day variation (repeatability).

Specificity Specificity according to Guidance for Industry Q2B Validation of Analytical Procedures: Methodology (1996) is defined as the ability to assess the analyte even in the presence of other components such as impurities, degradants and matrix, etc. Specificity was obtained by injecting blank nanoparticles containing all the

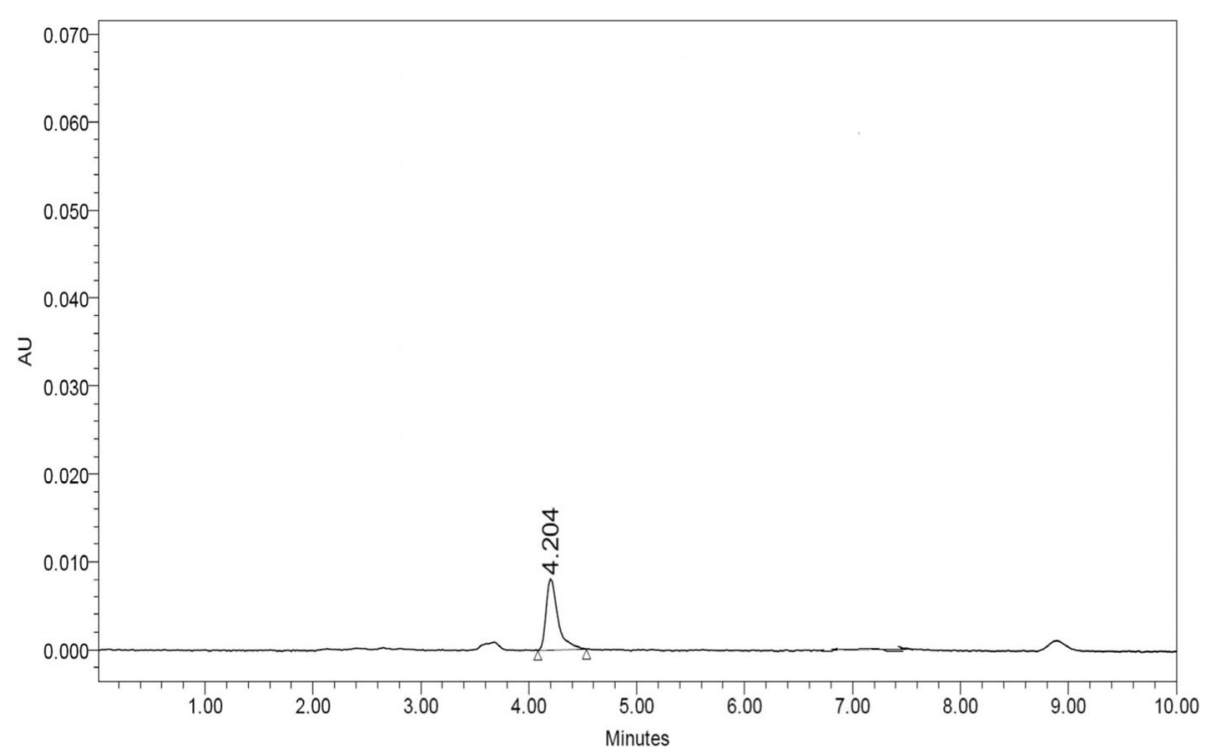

Fig. 2 Chromatogram showing absence of peak of naringenin of blank nanoparticles. The peak shown here depicts that of excipients present in formulation 
formulation components, except the drug, in the same quantity as were present in the naringenin-loaded nanoparticles. The chromatogram of the blank PLGA nanoparticles has been shown in (Fig. 2) while (Fig. 3) describes the chromatogram of the naringenin-loaded PLGA nanoparticles dissolved in methanol.

Recovery Absolute recovery is used to determine efficiency with which analyte is extracted from the matrix. It is also used to calculate and study the matrix effect (U.S. Department of Health and Human Services Food and Drug Administration). Recoveries were obtained at low, moderate, as well as high concentrations for both plasma samples $(200 \mathrm{ng} / \mathrm{ml}, 100 \mathrm{ng} / \mathrm{ml}$, and $50 \mathrm{ng} / \mathrm{ml})$ as well as from brain tissues $(12,500 \mathrm{ng} / \mathrm{ml}, 5000 \mathrm{ng} / \mathrm{ml}$, and $250 \mathrm{ng} / \mathrm{ml}$ ) respectively.

$$
\begin{aligned}
& \text { Absolute recovery }=100 X \text { (peak area of naringenin spiked into matrix } \\
& \div \text { peak area of the same concentration of naringenin in methanol) }
\end{aligned}
$$

Robustness Robustness indicates the reliability of the developed analytical procedure after the introduction of deliberate variations in the developed method which can affect its performance such as accuracy. The flow rate, mobile phase composition, $\mathrm{pH}$ of the mobile phase, column temperature, and injection volume were slightly changed to lower and higher sides of the actual values to find if there was any effect on the retention time. The flow rate was reduced to $0.6 \mathrm{ml} / \mathrm{min}$ and $0.8 \mathrm{ml} / \mathrm{min}$ from $1 \mathrm{ml} / \mathrm{min}$, mobile phase composition was changed to $60: 40$ ratio from $70: 30, \mathrm{pH}$ of mobile phase was changed by changing the concentration of ortho-phosphoric acid from 0.5 to $0.1 \%$ and $1 \%$, column temperature was varied to $35{ }^{\circ} \mathrm{C}$ from $30{ }^{\circ} \mathrm{C}$, and injection volume was varied from $20 \mu \mathrm{l}$ to $10 \mu \mathrm{l}$. Change in the retention time was observed and \% RSD values were calculated for each factor. The \% RSD values should be not more than (NMT) $2 \%$ in accordance with Q2B(R1) ICH guidelines for method validation (1996).

System suitability parameters System suitability, as defined by USP 32-NF27 (General Chapters: Validation of Compendial Methods 2009) (USP32-NF27 2006) and (Guidance for Industry Q2B Validation of Analytical Procedures: Methodology (1996) are those parameters such as number of theoretical plates $(\mathrm{N})$, tailing factor or asymmetry (A), limit of detection (LOD) $(\mu \mathrm{g} / \mathrm{ml})$, limit of quantification (LOQ) $(\mu \mathrm{g} / \mathrm{ml})$, and retention time $\left(R_{\mathrm{t}}\right)$, which give an indication about the analytical method being accurate, precise, and validated. These parameters were obtained after calculation and compared with the standard values to determine whether the

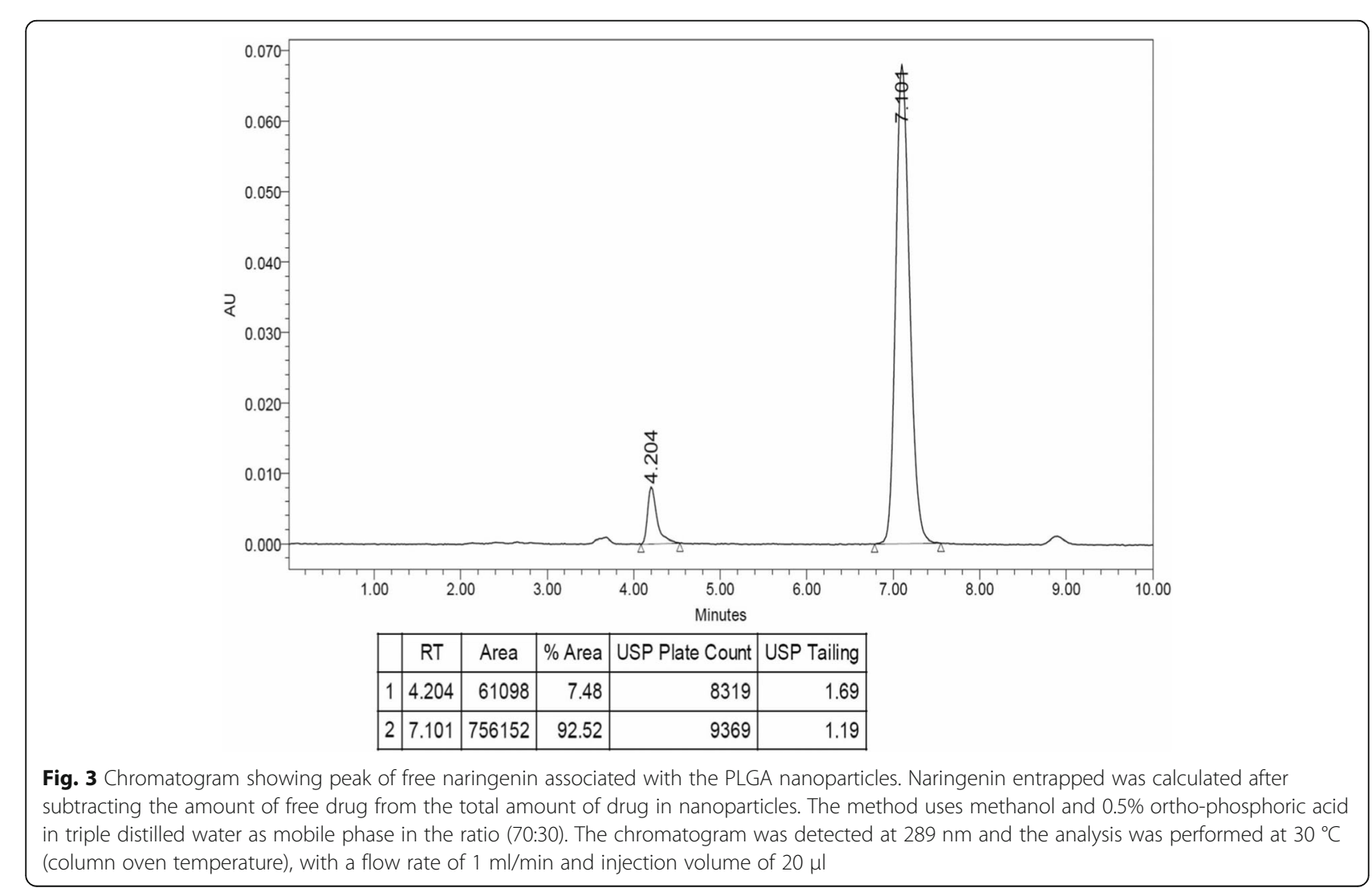


method being developed for naringenin was validated or not (Table 8).

\begin{abstract}
Applications of the developed analytical and bioanalytical method PLGA nanoparticles were formulated by significant modification of nanoprecipitation method developed by Fessi et al. (1989) with minor modifications. Detailed procedure is given in Additional file 1: Section S1. These were characterized for particle size and morphology, etc. The particle size of the nanoparticles, as determined by zetasizer, was $143.93 \mathrm{~nm}$ and was spherical in shape.
\end{abstract}

Determination of the entrapment efficiency of the PLGA nanoparticles This method was applied for the quantification of naringenin entrapped in the developed PLGA nanoparticles after minor modifications (Peter Christoper et al. 2014). One milliliter of prepared nanosuspension was centrifuged at $10,000 \pm 10 \mathrm{rpm}$ for 20 min to separate the free drug from the nanoparticles. The supernatant containing the free drug was diluted with methanol, filtered using $0.2 \mu \mathrm{m}$ syringe filter, and quantified using the developed RP-HPLC method. Entrapment efficiency was calculated using the expression

Entrapment efficiency $(\%)=$

Total drug added in formulation (mg)-free drug in formulation (mg) $\times 100$ total drug added in formulation $(\mathrm{mg})$

Method for determining the in-vitro release of naringenin from PLGA nanoparticles In-vitro release studies was performed using sample and separate method (D'Souza and DeLuca 2006; Xu et al. 2009). In this, $1.5 \mathrm{mg}$ of naringenin-loaded PLGA nanoparticles were suspended in $15 \mathrm{ml}$ of phosphate buffer, $(\mathrm{pH} 7.4)$, in a centrifuge tube. The centrifuge tube was shaken in a water bath shaker at $37{ }^{\circ} \mathrm{C}$. At predetermined time intervals, the tube was centrifuged at 12,000 rpm for $5 \mathrm{~min}$. The supernatant was collected and replaced with an equal volume of fresh phosphate buffer ( $\mathrm{pH}$ 7.4). The content of naringenin in supernatant was analyzed using HPLC. The drug release was determined at time intervals ranging from 0.25 to $24 \mathrm{~h}$. In-vitro release profiles of optimized naringenin-loaded poly(lactic-co-glycolic acid) (NGN-PLGA) nanoparticles were determined by the cumulative amount of naringenin released from nanoparticles at various time intervals points. As the release of the drug from PLGA encapsulated nanoparticles has been investigated using sample and separate method, the release of the free drug by this method is inconsequential (remains constant).

Pharmacokinetic studies The experimental protocol had been approved by Institutional Animal Ethics
Committee of Panjab University, Chandigarh (PU/IAEC/ S/14/108). Committee for the Purpose of Control and Supervision of Experiments on Animals (CPSEA) guidelines were adhered to for animal care. Eight-week-old male Sprague-Dawley (SD) rats weighing 200-250 g, obtained from Central Animal House at Panjab University, Chandigarh were used. The rats were housed individually in cages and given free access to standard laboratory food and water. The rats were fasted overnight before the experiment and were allowed to drink water ad libitum.

Blood samples were also collected from naive SD rats and plasma was separated by centrifugation. These blank plasma samples were used for validation of the method. For plasma pharmacokinetic studies, ten SD rats were randomly divided into two groups with five animals in each group. They were administered NGN and NGN-PLGA nanoparticles at a dose of $25 \mathrm{mg} / \mathrm{kg}$ by oral gavage. Naringenin suspension (unencapsulated naringenin), as well as lyophilized nanoparticles of naringenin, were suspended in $0.5 \%$ carboxymethylcellulose (CMC). Collection of blood samples was done by retroorbital venous plexus puncture under the influence of mild ether anesthesia. Samples were collected at following time points: $0.5 \mathrm{~h}, 1 \mathrm{~h}, 2 \mathrm{~h}, 4 \mathrm{~h}, 8 \mathrm{~h}, 12 \mathrm{~h}, 16 \mathrm{~h}, 20 \mathrm{~h}$, and $24 \mathrm{~h}$. The samples were collected and plasma was immediately separated by centrifugation at $10,000 \mathrm{rpm}$ for $10 \mathrm{~min}$. The plasma samples were stored at $-20^{\circ} \mathrm{C}$ for further analysis.

Ninety animals had been randomly divided into 2 groups with 45 animals in each group. Animals were administered with naringenin and naringenin-loaded PLGA nanoparticles as mentioned above. After dosing, brains were excised after sacrificing the animal with cervical dislocation at the same time points as those of plasma. The brain samples were stored at $-80{ }^{\circ} \mathrm{C}$ for further analysis. Brain tissues were also collected from naive rats and were used for validation of the method after preparing brain homogenate in phosphate buffer saline (PBS, 7.4 pH).

The plasma and brain samples containing naringenin as well as those spiked with standard concentrations of naringenin were further processed according to the method suitably optimized and validated for plasma and brain samples by us. In brief, $300 \mu$ l aliquots of plasma as well as brain homogenate (in PBS, 7.4 pH) were added to clean Eppendorf $(2 \mathrm{ml})$ tubes, followed by $200 \mu \mathrm{l}$ of mixture of methanol and $0.5 \%$ ortho-phosphoric acid in the ratio of (70:30) for plasma and $400 \mu \mathrm{l}$ for brain tissue samples. This was added to promote efficient extraction of the drug. The samples were then vortexed for $2 \mathrm{~min}$ and $500 \mu \mathrm{l}$ of acetonitrile was added to plasma as well as brain homogenate samples in order to precipitate proteins. The samples were then centrifuged at $15,000 \mathrm{rpm}$ for $15 \mathrm{~min}$ and the supernatant was transferred to fresh Eppendorf tubes. 
The supernatant was filtered using $0.22 \mu \mathrm{m}$ nylon syringe filter. Subsequently, $20 \mu \mathrm{l}$ aliquots of each supernatant were analyzed with HPLC system.

Pharmacokinetic analysis Plasma and brain concentrations were analyzed with PK Solver 2.0 (Microsoft-Excel Add-Ins program) using the built-in non-compartmental analysis (NCA) method of calculation. In this method, the areas under concentration-time curves (AUC) were calculated by a linear trapezoidal method as well as the maximum concentration of the drug in plasma and brain $\left(C_{\max }\right)$ was also calculated. Both these parameters were specifically calculated to calculate the relative bioavailability of the formulation as well as the brain to plasma ratio of naringenin in order to study the enhanced uptake after its incorporation into nanoparticles. Relative bioavailability of the formulation was also calculated as follows: $F_{\mathrm{r}}=\mathrm{AUC}_{0 \rightarrow \infty}$ (formulation) / $\mathrm{AUC}_{0 \rightarrow \infty}$ (NGN suspension). Other parameters such as half-life $\left(t_{1 / 2}\right), T_{\max }$, volume of distribution (Vd), clearance $(\mathrm{CL})$, mean residence time (MRT), and elimination rate constant $(\mathrm{Ke})$ were also determined.

Brain-to-plasma ratio Brain-to-plasma partition coefficients $(\mathrm{Kp})$ of naringenin was calculated as described by (Gáll et al. (2015) from the ratio of the mean brain and plasma concentrations $\left(C_{\max }\right)$ as well as $\mathrm{AUC}_{0 \rightarrow \infty}$ but with minor modifications in the method.

\section{Results}

HPLC method development

The method utilizing methanol and water in the ratio of 70:30 with water containing $0.5 \%$ ortho-phosphoric acid ( $\mathrm{pH} 2.47$ ) yielded a sharp, symmetric peak at the flow rate of $1 \mathrm{ml} / \mathrm{min}$. The maximum absorption of naringenin was detected at $289 \mathrm{~nm}$, and this wavelength was chosen for its determination. The addition of $0.5 \%$ ortho-phosphoric acid improved the separation of naringenin by suppressing its ionization and reduced peak tailing resulting in a sharp symmetric peak with a retention time $\left(R_{\mathrm{t}}\right)$ of $7.2 \mathrm{~min}$ in the standard solution of $40 \mu \mathrm{g} / \mathrm{ml}$. The chromatogram is shown in (Fig. 4).

The same method was used for quantification of naringenin in plasma and brain tissue except that the flow rate was reduced to $0.8 \mathrm{ml} / \mathrm{min}$ in order to reduce the slight peak tailing observed and as a result of which $R_{\mathrm{t}}$ was changed slightly to $5.99 \mathrm{~min}$.

\section{Linearity}

The linear range for naringenin was evaluated within the range of $0.5-40 \mu \mathrm{g} / \mathrm{ml}$. The stock solution of naringenin was diluted to seven different concentrations in the range of $0.5-40 \mu \mathrm{g} / \mathrm{ml}$ and a calibration curve was obtained by plotting peak area versus concentration of naringenin $(\mu \mathrm{g} / \mathrm{ml})$. A straight line was obtained over the entire concentration range. Linear regression analysis was used to calculate the linearity equation. The

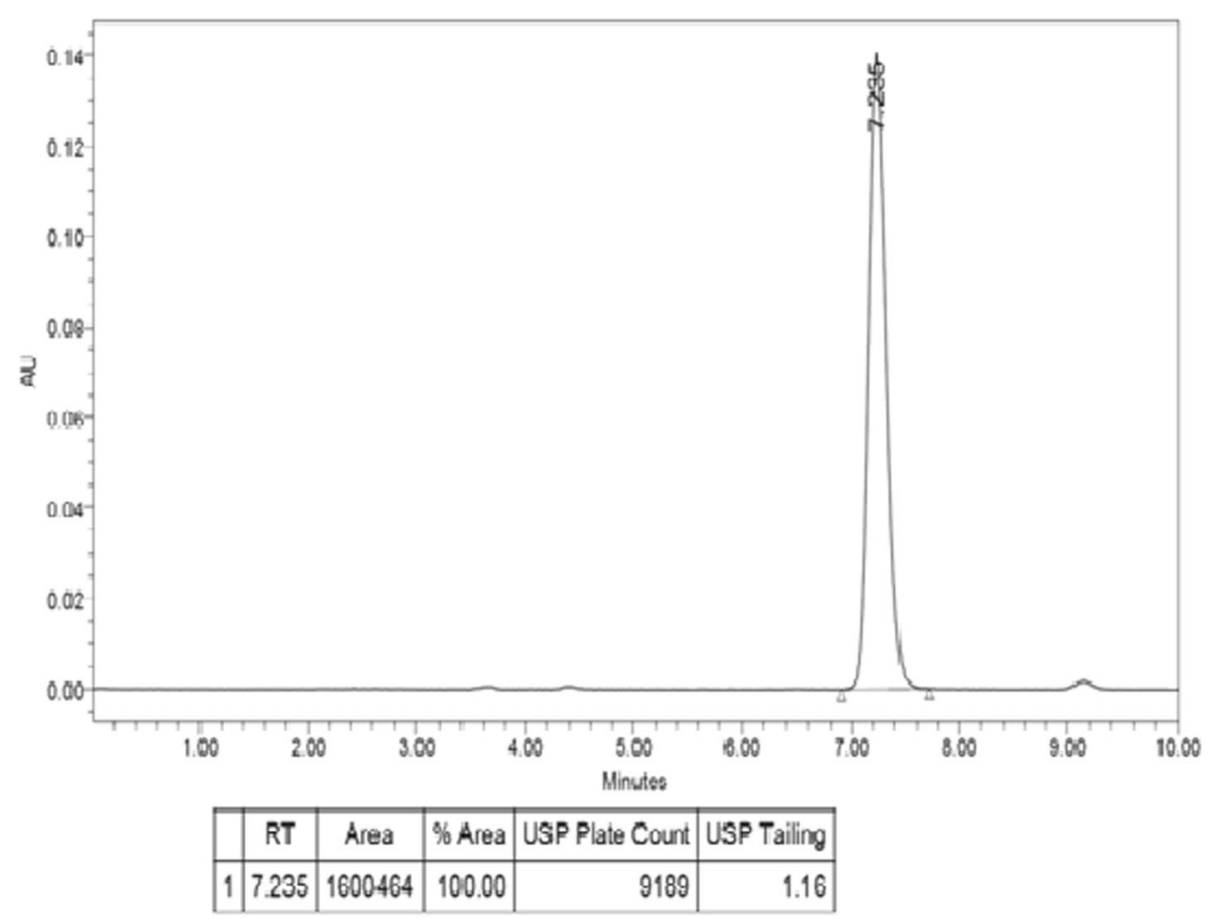

Fig. 4 The chromatogram of standard solution of naringenin 


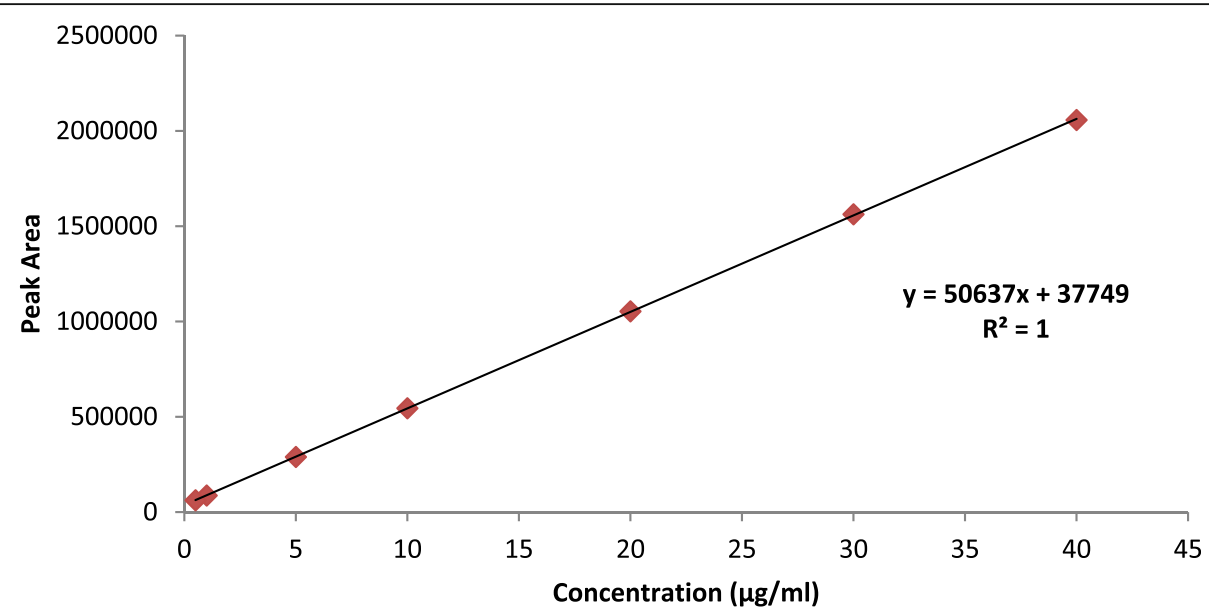

Fig. 5 Calibration plot of naringenin in methanol using methanol and $0.5 \%$ ortho-phosphoric acid in MilliQ water as mobile phase in the ratio of (70:30). The chromatogram was detected at $289 \mathrm{~nm}$ and the analysis was performed at $30^{\circ} \mathrm{C}$ (column oven temperature), with a flow rate of $1 \mathrm{ml} / \mathrm{min}$ and injection volume of $20 \mu \mathrm{l}$. The range of the calibration curve was $0.5 \mu \mathrm{g} / \mathrm{ml}$ to $40 \mu \mathrm{g} / \mathrm{ml}$

calibration curve equation was $y=50,637 x+37,749$, with a determination factor $R^{2}=1$ (Fig. 5).

Multiple linear regression analysis was performed using MS-Excel Data analysis Tool-Pack. The regression statistics showed the value of the coefficient of determination $\left(R^{2}\right)$ to be 0.999977 . Using analysis of variance (ANOVA) on the regression line yielded very small $F$ and $p$ values $\left(F=8.50643 \times 10^{-13}, p=1.38254 \times 10^{-5}\right)$ at $99 \%$ confidence level. Residual analysis in regression shows a random pattern of the residuals as indicated by the residual plot (Fig. 6). While the regression statistics showed the value of the coefficient of determination $\left(R^{2}\right)$ to be 0.997538 and 1 for plasma and brain tissue samples respectively.

The linearity for the bio-analytical method was established by three repeated injections of rat plasma and brain tissue homogenate spiked with naringenin concentrations of $31.5-1000 \mathrm{ng} / \mathrm{ml}$ and $0.125-50 \mu \mathrm{g} / \mathrm{ml}$ respectively. A plot of peak area with respect to corresponding concentration was used to demonstrate linearity. The linear range for naringenin was evaluated within the range of $6.3-200 \mathrm{ng} / \mathrm{ml}$ for plasma and 31.25$12,500 \mathrm{ng} / \mathrm{ml}$ for the brain. The calibration curve obtained by plotting peak area versus concentration of naringenin resulted in a straight line over the entire concentration range. Linear regression analysis was used to calculate the linearity equation. The calibration curve equation was $y=152.49+1590.8 \quad\left(R^{2}=0.9975\right)$ for plasma (Fig. 7) and $y=81.505 x+8186.9$, with a determination factor $R^{2}=1$, for brain tissue (Fig. 8). The regression statistics showed the value of the coefficient of determination $\left(R^{2}\right)$ to be 0.997538 and 1 for plasma and brain tissue samples respectively. Sample chromatograms of blank plasma and brain tissue as well as blank plasma and brain tissue spiked with naringenin have been shown in Additional file 1: Figure S1.

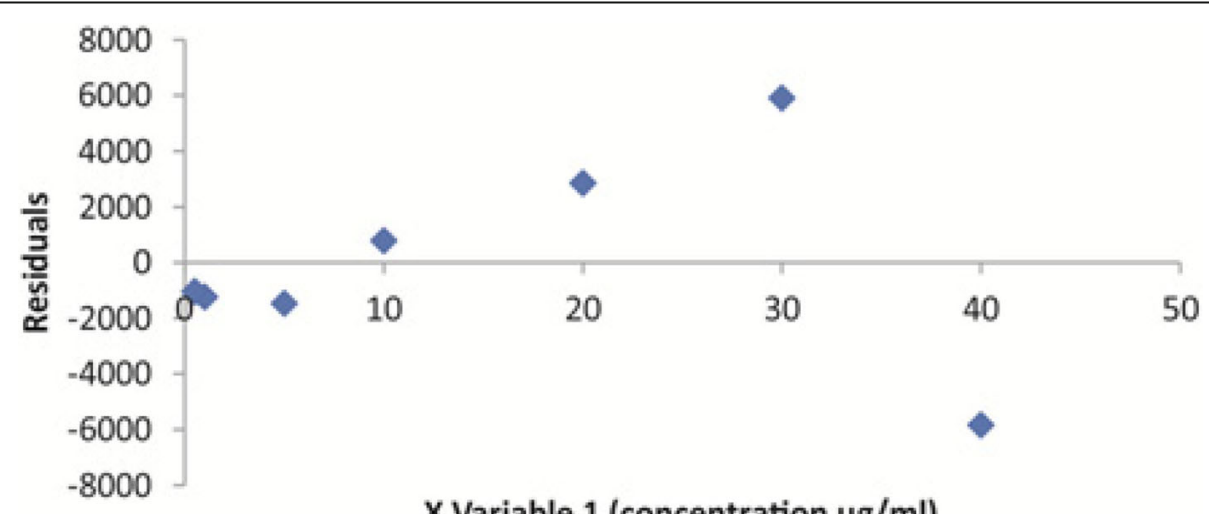

$\mathrm{X}$ Variable 1 (concentration $\mu \mathrm{g} / \mathrm{ml}$ )

Fig. 6 Residual plot indicating appropriateness of the linear regression model 


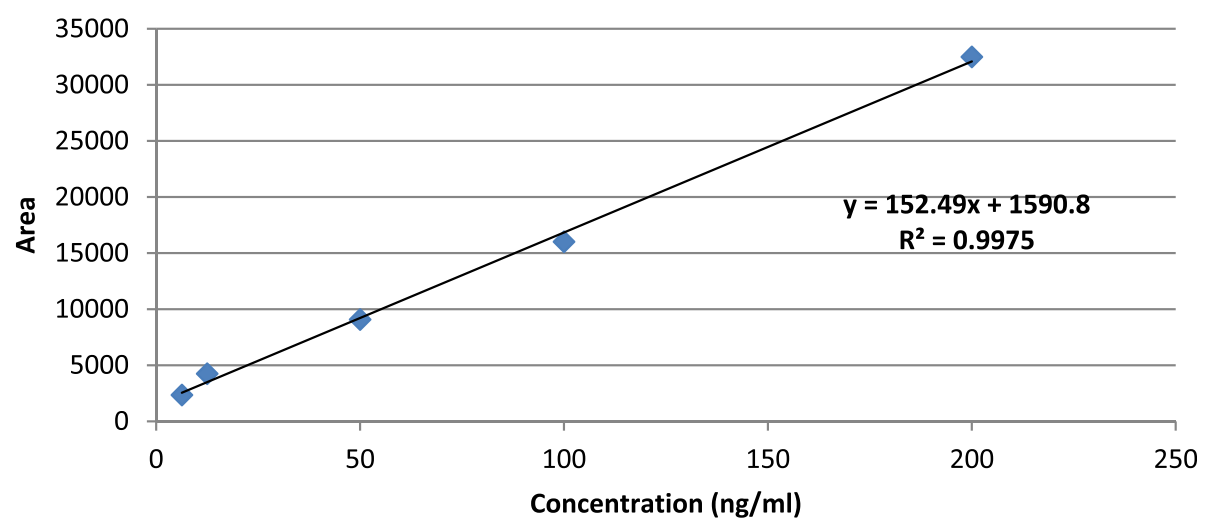

Fig. 7 Calibration plot of naringenin in rat plasma

\section{Limit of detection and limit of quantification}

Limit of detection (LOD) and limit of quantification (LOQ) of naringenin were obtained using calibration curve analysis; LOD and LOQ were found to be $0.15 \mu \mathrm{g} / \mathrm{ml}$ and $0.44 \mu \mathrm{g} / \mathrm{ml}$ respectively. While LOD and LOQ in plasma, as well as brain samples, were calculated to be $9.71 \mathrm{ng} / \mathrm{ml}$ and $29.44 \mathrm{ng} / \mathrm{ml}$ as well as $9.06 \mathrm{ng} / \mathrm{ml}$ and $27.44 \mathrm{ng} / \mathrm{ml}$, respectively. Pharmacokinetic analysis of plasma and brain has indicated that at $24 \mathrm{~h}$, concentration of naringenin in plasma was $18.6 \mathrm{ng} / \mathrm{ml}$ and in brain concentration was $9.91 \mathrm{ng} / \mathrm{ml}$. Therefore, a sensitive method with LOD as low as $9 \mathrm{ng} / \mathrm{ml}$ is required, which is the case with our method. The same has been described in the text on page 15 .

\section{Accuracy}

The accuracy for the analytical method was determined in the range of $5 \mu \mathrm{g} / \mathrm{ml}$ to $40 \mu \mathrm{g} / \mathrm{ml}$ (Table 1). The accuracy was determined in the range from 50 to $200 \mathrm{ng} / \mathrm{ml}$ for plasma (Table 2) as well as from 250 to $12,500 \mathrm{ng} / \mathrm{ml}$ for brain tissue (Table 3 ).

The excellent mean recovery values which are close to $100 \%$ and their low values of relative standard deviation
(\% RSD) which is $<2 \%$ depict high accuracy of the analytical as well as bio-analytical method.

\section{Precision}

The precision (\% RSD) of the developed analytical as well as the bio-analytical method was evaluated by calculating intra-day and inter-day coefficient of variation. Precision was determined for an analytical method by studying the intra-day variability or repeatability as well as inter-day variability ranging from 5 to $40 \mu \mathrm{g} / \mathrm{ml}$ at all three concentrations of naringenin in triplicate $(n=3)$ (Table 4). For plasma, the range was from 50 to $200 \mathrm{ng} /$ $\mathrm{ml}$ (Table 5) and it was from 250 to $12,500 \mathrm{ng} / \mathrm{ml}$ for brain tissue (Table 6). The intra-day variability studies indicate the precision after a short interval of time within a day under the same operating conditions. Inter-day variability is the precision study over three different days. Percentage relative standard deviation (\% RSD) were found within the limit of $2 \%$ in all cases. RSD values were within the acceptable range indicating that the developed analytical, as well as bio-analytical method, is precise.

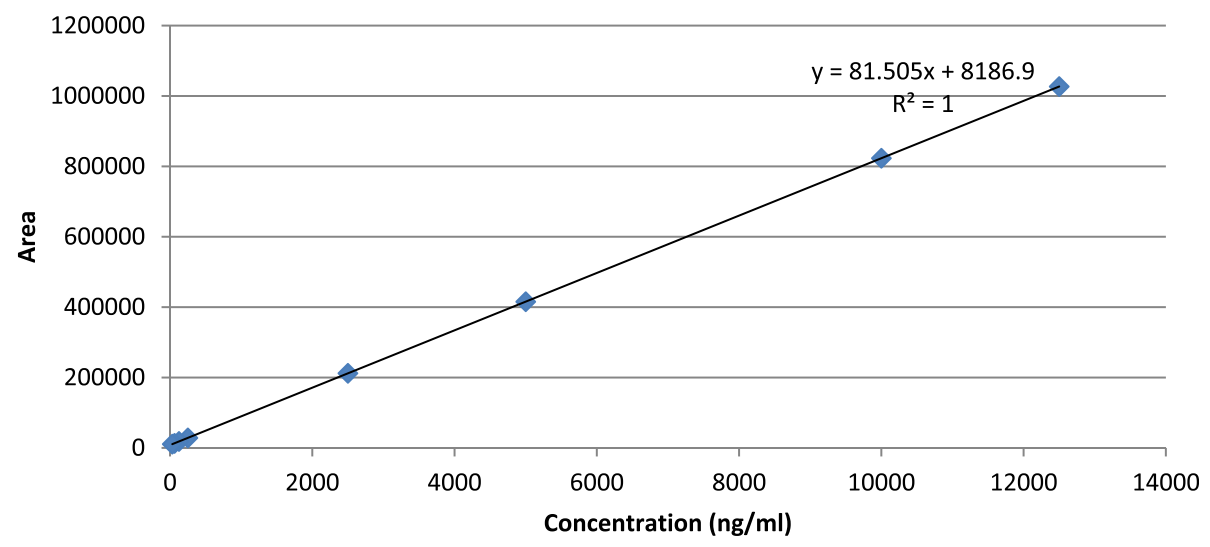

Fig. 8 Calibration plot of naringenin in brain tissue of rat 
Table 1 Accuracy data for the developed analytical method for naringenin

\begin{tabular}{llll}
\hline $\begin{array}{l}\text { Conc } \\
(\mu \mathrm{g} /\end{array}$ & \multicolumn{3}{l}{ Predicted concentration } \\
\cline { 2 - 4 } $\mathrm{ml})$ & Mean $\pm \mathrm{SD}$ & \% RSD & Accuracy \% \\
\hline 5 & $5.11 \pm 0.06$ & 1.19 & 102.38 \\
20 & $20.29 \pm 0.01$ & 0.06 & 101.48 \\
40 & $40.53 \pm 0.11$ & 0.28 & 101.34 \\
\hline
\end{tabular}

Data are expressed as (mean $\pm \mathrm{SD}, n=3$ )

\section{Specificity}

The absence of the peak of naringenin in the chromatogram of blank nanoparticles (Fig. 2) and presence of a peak of naringenin in the chromatogram of PLGA nanoparticles containing naringenin at Rt 7.1 in methanol (Fig. 3) indicates the specificity of the developed method.

\section{Recovery}

The recoveries of naringenin from plasma were 94.61, 98.22, $101.32 \%$ for concentrations of 50, 100, and $200 \mathrm{ng} / \mathrm{ml}$, respectively. The recoveries from brain tissue homogenate were 99.99, 99.94, 99.98\% for concentrations of 250, 5000, and 12,500 ng/ml, respectively.

\section{Robustness}

Robustness of the developed analytical method was found by varying the parameters such as injection volume to $10 \mu \mathrm{l}$ from $20 \mu \mathrm{l}$, flow rate to 0.6 and $0.8 \mathrm{ml} / \mathrm{min}$ from $1 \mathrm{ml} / \mathrm{min}$, column temperature to $35^{\circ} \mathrm{C}$, mobile phase ratio to 60:40 from 70:30, and $\mathrm{pH}$ of the mobile phase by varying the concentration of ortho-phosphoric acid from 0.5 to $0.1 \%$ and $1 \%$. (Table 7 ). Injections were given in triplicate for each parameter. The percentage RSD was calculated for observing any deviation in the retention time on variation in these parameters. The percentage of RSD was found to be in the range of $1.2-2 \%$.

\section{System suitability parameters}

The system suitability parameters were calculated and were in accordance of the ICH Q2B guidelines for the validation of analytical procedure (1996) (1996) as well as the United States Pharmacopeia (USP 32-NF-27), 2009 (USP32-NF27.) (Table 8).

Table 2 Accuracy data for the developed bio-analytical method for naringenin in rat plasma

\begin{tabular}{llll}
\hline $\begin{array}{l}\text { Conc } \\
(\mathrm{ng} /\end{array}$ & \multicolumn{2}{l}{ Predicted concentration } & \\
\cline { 2 - 4 } $\mathrm{ml})$ & Mean \pm SD & \% RSD & Accuracy \% \\
\hline 200 & $202.70 \pm 0.006$ & 0.0064 & 101.35 \\
100 & $94.68 \pm 0.01$ & 0.011 & 94.68 \\
50 & $49.21 \pm 0.026$ & 0.054 & 98.41 \\
\hline
\end{tabular}

Data are expressed as (mean $\pm S D, n=3$ )
Table 3 Accuracy data for the developed bio-analytical method for naringenin in rat brain tissue

\begin{tabular}{|c|c|c|c|}
\hline \multirow{2}{*}{$\begin{array}{l}\text { Conc } \\
\text { (ng/ } \\
\mathrm{ml} \text { ) }\end{array}$} & \multicolumn{3}{|c|}{ Predicted concentration } \\
\hline & Mean \pm SD & $\%$ RSD & Accuracy \% \\
\hline 12,500 & $11,852.300 \pm 0.043$ & 0.0004 & 94.82 \\
\hline 5000 & $4976.66 \pm 0.06$ & 0.001 & 99.53 \\
\hline 250 & $250.09 \pm 0.037$ & 0.015 & 100.04 \\
\hline
\end{tabular}

Data are expressed as (mean $\pm \mathrm{SD}, n=3$ )

\section{Applicability of the developed RP-HPLC method for determination of naringenin}

The developed and validated method was applied for the determination of in-vitro release of naringenin from the nanoparticles as well as entrapment efficiency (\%) of naringenin in the PLGA nanoparticles (Fig. 3). Then, $81.8 \%$ of the drug was released in $24 \mathrm{~h}$.

The peak of naringenin in the PLGA nanoparticles was obtained at $7.101 \mathrm{~min}$ (Fig. 3). The concentration of free naringenin associated with the nanoparticles was found to be $14 \mu \mathrm{g} / \mathrm{ml}$. Hence, entrapment efficiency was found to be $95.33 \%$ as the concentration of naringenin in the nanoparticles is $300 \mu \mathrm{g} / \mathrm{ml}$.

\section{Single-dose pharmacokinetic and brain-uptake study}

The in-vivo pharmacokinetic study was performed to quantify naringenin in plasma and brain after oral administration of naringenin-loaded PLGA nanoparticles. The objective of the study was to determine the improvement in bioavailability of naringenin after its formulation into nanoparticles as well as to quantify the uptake of naringenin in the brain by evaluating the pharmacokinetic parameters in the brain as well as by studying the brain: plasma ratio of the drug. Our results showed that the pharmacokinetic parameters fitted non-compartmental model. The statistical analysis of data was performed using one-way analysis of variance (ANOVA) at $5 \%$ level of significance $(p \leq 0.05)$ followed by Tukey's multiple comparison test.

\section{Plasma PK}

The $C_{\max }$ of naringenin-loaded nanoparticles in plasma was $5323.08 \pm 0.57 \mathrm{ng} / \mathrm{ml}$ as compared to naringenin suspension whose $C_{\max }$ was $4227.08 \mathrm{ng} / \mathrm{ml}$. While the

Table 4 Precision study of the HPLC analysis of naringenin

\begin{tabular}{|c|c|c|c|c|c|c|}
\hline \multirow{2}{*}{$\begin{array}{l}\text { Conc } \\
\text { taken } \\
\text { (mcg/ } \\
\text { ml) }\end{array}$} & \multicolumn{3}{|c|}{ Intra-day variation } & \multicolumn{3}{|c|}{ Inter-day variation } \\
\hline & $\begin{array}{l}\text { Conc found } \\
\text { (Mean } \pm \text { SD) }\end{array}$ & $\begin{array}{l}\% \\
\text { RSD }\end{array}$ & $\begin{array}{l}\% \\
\text { Accuracy }\end{array}$ & $\begin{array}{l}\text { Conc found } \\
\text { (Mean } \pm S D)\end{array}$ & $\begin{array}{l}\% \\
\text { RSD }\end{array}$ & Accuracy \\
\hline 5 & $5.101 \pm 0.060$ & 1.17 & 102.02 & $5.13 \pm 0.043$ & 0.85 & 102.72 \\
\hline 20 & $20.832 \pm 0.114$ & 0.55 & 104.16 & $20.924 \pm 0.262$ & 1.26 & 104.62 \\
\hline 40 & $39.90 \pm 0.67$ & 1.7 & 99.66 & $40.300 \pm 0.158$ & 0.39 & 100.75 \\
\hline
\end{tabular}

Data are expressed as mean $\pm \mathrm{SD} ; n=3$ 
Table 5 Precision of the assay for naringenin in rat plasma

\begin{tabular}{|c|c|c|c|c|c|c|}
\hline \multirow{2}{*}{$\begin{array}{l}\text { Conc } \\
\text { (ng/ } \\
\mathrm{ml} \text { ) }\end{array}$} & \multicolumn{3}{|c|}{ Inter-day variation } & \multicolumn{3}{|c|}{ Intra-day variation } \\
\hline & $\begin{array}{l}\text { Conc found } \\
\text { (Mean } \pm S D)\end{array}$ & $\begin{array}{l}\% \\
\text { RSD }\end{array}$ & $\begin{array}{l}\% \\
\text { Accuracy }\end{array}$ & $\begin{array}{l}\text { Conc found } \\
\text { (Mean } \pm S D)\end{array}$ & $\begin{array}{l}\% \\
\mathrm{RSD}\end{array}$ & Accuracy \\
\hline 200 & $\begin{array}{l}202.672 \pm \\
0.0075\end{array}$ & 0.004 & 101.34 & $\begin{array}{l}202.68 \pm \\
0.014\end{array}$ & 0.007 & 101.34 \\
\hline 100 & $\begin{array}{l}94.632 \pm \\
0.0057\end{array}$ & 0.006 & 94.632 & $94.63 \pm 0.011$ & 0.11 & 94.63 \\
\hline 50 & $\begin{array}{l}49.133 \pm \\
0.0082\end{array}$ & 0.016 & 98.267 & $49.14 \pm 0.008$ & 0.015 & 98.27 \\
\hline
\end{tabular}

Data are expressed as mean $\pm S D ; n=3$

$\mathrm{AUC}_{0 \rightarrow \infty}$ for naringenin nanoparticles was 43,019.92 \pm $9.65 \mathrm{ng} \times \mathrm{h} / \mathrm{ml}$ as compared to naringenin suspension whose $\mathrm{AUC}_{0 \rightarrow \infty}$ was 25,460.66 $\pm 3.27 \mathrm{ng} \times \mathrm{h} / \mathrm{ml}$. The AUC $0 \rightarrow \infty, C_{\max }$, and $F_{\mathrm{r}}$ (relative bioavailability) of NGN-PLGA nanoparticles after oral administration were approximately 1.68 times $(p<0.05), 1.26$ times $(p<0.05)$, and 1.69 times higher as compared to those of naringenin suspension (NGN-Suspension), respectively (our unpublished data). The other pharmacokinetic parameters such as $t_{1 / 2}, T_{\max }, \mathrm{Vd}, \mathrm{CL}, \mathrm{MRT}$, and Ke of naringenin suspension and nanoparticles in plasma were also obtained and showed similar trend.

\section{Brain PK}

The $C_{\max }$ of naringenin-loaded nanoparticles in brain tissues was $1380.07 \pm 0.54 \mathrm{ng} / \mathrm{ml}$ as compared to naringenin suspension whose $C_{\max }$ was $836.96 \pm 0.315 \mathrm{ng} / \mathrm{ml}$. While the $\mathrm{AUC}_{0 \rightarrow \infty}$ for naringenin nanoparticles was $10,890.05 \pm 16.29 \mathrm{ng} \times \mathrm{h} / \mathrm{ml}$ as compared to naringenin suspension whose $\mathrm{AUC}_{0 \rightarrow \infty}$ was $4937.56 \pm 1.96 \mathrm{ng} \times \mathrm{h} /$ $\mathrm{ml}$. The AUCO $\rightarrow \infty, C_{\max }$, and $F_{\mathrm{r}}$ (relative bioavailability) of NGN-PLGA nanoparticles in the brain after oral administration were approximately 2.26 times $(p<0.05)$, 1.64 times $(p<0.05)$, and 2.26 times higher as compared to that of naringenin suspension (NGN-Suspension), respectively (our unpublished data). The other pharmacokinetic parameters such as $t_{1 / 2}, T_{\max }, \mathrm{Vd}, \mathrm{CL}, \mathrm{MRT}$, and Ke of Naringenin suspension and nanoparticles in brain were also obtained and showed similar trend.

Table 6 Precision of the assay for naringenin in rat brain

\begin{tabular}{|c|c|c|c|c|c|c|}
\hline \multirow{2}{*}{$\begin{array}{l}\text { Conc } \\
\text { taken } \\
\text { (ng/ } \\
\mathrm{ml})\end{array}$} & \multicolumn{3}{|c|}{ Inter-day variation } & \multicolumn{3}{|c|}{ Intra-day variation } \\
\hline & $\begin{array}{l}\text { Conc found } \\
\text { (Mean } \pm \text { SD) }\end{array}$ & $\begin{array}{l}\% \\
\text { RSD }\end{array}$ & $\begin{array}{l}\% \\
\text { Accuracy }\end{array}$ & $\begin{array}{l}\text { Conc found } \\
\text { (Mean } \pm S D)\end{array}$ & $\begin{array}{l}\% \\
\text { RSD }\end{array}$ & $\begin{array}{l}\% \\
\text { Accuracy }\end{array}$ \\
\hline 12,500 & $\begin{array}{l}11,852.27 \pm \\
0.033\end{array}$ & 0.0002 & 94.818 & $\begin{array}{l}11,852.24 \pm \\
0.02\end{array}$ & 0.0002 & 94.82 \\
\hline 5000 & $\begin{array}{l}4976.63 \pm \\
0.054\end{array}$ & 0.001 & 99.53 & $\begin{array}{l}4976.60 \pm \\
0.009\end{array}$ & 0.0001 & 99.53 \\
\hline 250 & $\begin{array}{l}250.04 \pm \\
0.024\end{array}$ & 0.009 & 100.014 & $\begin{array}{l}250.043 \pm \\
0.012\end{array}$ & 0.005 & 100.08 \\
\hline
\end{tabular}

Data are expressed as mean \pm SD; $n=3$
Table 7 Effect of variation in the parameters on the retention time

\begin{tabular}{|c|c|c|c|}
\hline S. No & Parameters varied & Condition & Retention time (min) \\
\hline \multirow[t]{5}{*}{1} & \multirow[t]{5}{*}{ Injection volume $(\mu \mathrm{l})$} & 20 & 7.097 \\
\hline & & 10 & 7.22 \\
\hline & & Mean & 7.1585 \\
\hline & & SD & 0.086974134 \\
\hline & & $\%$ RSD & 1.214977077 \\
\hline \multirow[t]{6}{*}{2} & \multirow[t]{6}{*}{ Flow rate (ml/min) } & 0.6 & 7 \\
\hline & & 0.8 & 6.8 \\
\hline & & 1 & 7 \\
\hline & & Mean & 6.9 \\
\hline & & SD & 0.141421356 \\
\hline & & $\%$ RSD & 2.049584873 \\
\hline \multirow[t]{5}{*}{3} & \multirow[t]{5}{*}{ Mobile phase ratio } & Ratio (60:40) & 6.8 \\
\hline & & Ratio (70:30) & 7 \\
\hline & & Mean & 6.9 \\
\hline & & SD & 0.141421356 \\
\hline & & $\%$ RSD & 2.049584873 \\
\hline \multirow[t]{5}{*}{4} & \multirow[t]{5}{*}{ Column temp $\left({ }^{\circ} \mathrm{C}\right)$} & $35^{\circ} \mathrm{C}$ & 7 \\
\hline & & $30^{\circ} \mathrm{C}$ & 7.2 \\
\hline & & Mean & 7.1 \\
\hline & & SD & 0.141421356 \\
\hline & & $\%$ RSD & 1.991850088 \\
\hline \multirow[t]{6}{*}{5} & \multirow[t]{6}{*}{$\mathrm{pH}$ of mobile phase } & 1\% OPA (pH 2.27) & 7.05 \\
\hline & & $0.1 \%$ OPA (pH 2.97) & 7.084 \\
\hline & & $0.5 \%$ OPA (pH 2.47) & 7.22 \\
\hline & & Mean & 7.152 \\
\hline & & SD & 0.096166522 \\
\hline & & $\%$ RSD & 1.34461021 \\
\hline
\end{tabular}

\section{Brain:plasma ratio}

Brain-to-plasma ratios $(\mathrm{Kp})\left(C_{\mathrm{br}} / C_{\mathrm{pl}}\right)$ was significantly higher after administration of naringenin-loaded nanoparticles as compared to naringenin suspension. NGN-PLGA-NPs also showed increased uptake as compared to naringenin

Table 8 System suitability parameters

\begin{tabular}{lll}
\hline Parameters & Obtained values & Standard values \\
\hline Theoretical plate & 9189 & $\geq 2000$ \\
Asymmetry & 1.1 & $<2(0.9-1.1)$ \\
LOD $(\mu \mathrm{g} / \mathrm{ml})$ & $0.1 \mu \mathrm{g} / \mathrm{ml}$ & $3^{*}($ signal/noise $)$ \\
LOQ $(\mu \mathrm{g} / \mathrm{ml})$ & $0.44 \mu \mathrm{g} / \mathrm{ml}$ & $10^{*}$ (signal/noise) \\
Retention time & 7.1 & $>2$ \\
Precision & $0.5-1.2$ (intra-day and inter-day) & RSD $\leq 2$ \\
Accuracy & $0.28-1.19$ & $\mathrm{RSD} \leq 2$ \\
\hline
\end{tabular}


suspension $\left.\left[\left(F_{3,8}=195,298\right), p<0.0001\right)\right]$ (our unpublished data) (Additional file 1: Table S1).

The results of pharmacokinetic studies for plasma as well as brain indicate that after administration of NGN-PLGA nanoparticles, there was an increased absorption of NGN after oral administration as compared to NGN-Suspension as indicated by the increase in the AUC and $C_{\max }$. The relative bioavailability of NGN-PLGA nanoparticles was found to be $\sim 1.7$ times more as compared to naringenin suspension. Similar results were obtained by other research groups where there was increase in bioavailability of naringenin after its incorporation into delivery systems which enhance dissolution and prolong the circulation time because of their small size, bypassing the reticuloendothelial system (Ji et al. 2016; Khan et al. 2015; SUSEELA et al. 2015). The results of brain to plasma ratio of the availability of the drug also indicated that there was enhanced uptake in the brain after incorporation of naringenin into nanoparticles. The plausible reason for enhanced uptake of naringenin across the $\mathrm{BBB}$ after incorporation into nanocarriers as compared to unencapsulated naringenin was improved oral bioavailability of naringenin as also evident from the results of plasma pharmacokinetic studies. Encapsulation of naringenin into nanocarriers also prevents its metabolic degradation and early elimination from the body. Naringenin nanocarriers will be better absorbed as compared to unencapsulated naringenin because its low solubility leading to poor bioavailability has been overcome after its incorporation into nanocarriers. Similar results have also been obtained by other research groups (Jain et al. 2015; Muthu et al. 2009; Tiwari et al. 2014) indicating beneficial effects of nanocarriers in targeting brain. There will be prolonged release from the nanocarriers. We had also found in our study that brain uptake of these nanocarriers was enhanced as they inhibit P-gp efflux transporters at the blood-brain barriers (Bhandari et al. 2018). This inhibition was enhanced after surface modification of naringenin nanocarriers with reduced glutathione (GSH) and Tween 80 (Bhandari et al. 2018). Naringenin nanoparticles show their effect in attenuation of neuroinflammation and reduction in oxidative stress mediated mitochondrial dysfunction and biochemical deficit in autism spectrum disorder at dose of $25 \mathrm{mg} / \mathrm{kg}$, and this effect was found to be comparable to the $100 \mathrm{mg} / \mathrm{kg}$ dose of unencapsulated or free naringenin (Bhandari et al. 2018).

\section{Discussion}

The method was linear within the range of $0.5-40 \mu \mathrm{g} / \mathrm{ml}$ as indicated from the value of determination factor which was found to be 1, yielding the best fit line. Multiple regression analysis using MS-Excel analysis Tool-Pack showed the value of 0.999972 of the adjusted coefficient of determination $\left(R^{2}\right)$ which suggests that $99.99 \%$ variance of the dependent variable $y$, i.e., peak area, is explained by the variance of the independent variable, i.e., concentration. Results of ANOVA show that the probability of obtaining the predicted regression output by random chance is nearly zero at 99\% confidence level. Residual analysis indicates appropriateness of the linear regression model. The precision and accuracy were found to be in accordance with the $\mathrm{ICH}$ guidelines as indicated from the mean recovery values and low values of \% RSD which were within the acceptable limits. Method was also found to be robust as \% RSD values obtained after varying various parameters were within the acceptable limits. The system suitability parameters were within the permissible limits laid down by ICH Q2B guidelines and USP 32-NF-27, indicating that the developed analytical method for naringenin was accurate, precise, and robust. When this developed and validated method was further applied for quantification of naringenin in the developed PLGA nanoparticles as well as for in-vitro release, there was no unwanted peak or shift in the retention time of the drug indicating the sensitivity as well as selectivity of the developed and validated RP-HPLC method. The entrapment efficiency of the nanoparticles was found to be $95.33 \%$ while the in-vitro drug release was $81.8 \%$ in $24 \mathrm{~h}$. This developed and validated method could not only be used for determining the entrapment efficiency and in-vitro release of naringenin from nanoparticles but could be used for determination of pharmacokinetic parameters of naringenin in plasma and brain as well the ratio of uptake of naringenin in brain with respect to plasma. The bio-analytical method was also found to be linear, precise, accurate, and specific with a good recovery and minimum matrix effect. The permissible limits of the validation parameters complied to the bio-analytical method validation guidelines (U.S. Department of Health and Human Services Food and Drug Administration). There was slight shift in retention time in plasma and brain samples from $R_{\mathrm{t}} 7.0$ to $R_{\mathrm{t}} 5.99$ as a result of change in flow rate from 1 to $0.8 \mathrm{ml} / \mathrm{min}$ as slight peak tailing was observed. Rest all the column parameters were the same as those used for analytical method validation. The developed bio-analytical method was used for quantification of naringenin in plasma and brain. The results of pharmacokinetic studies for plasma as well as brain indicate that after administration of NGN-PLGA nanoparticles, there was an increased absorption of NGN after oral administration as compared to NGN-Suspension as indicated by the increase in the AUC and $C_{\max }$. Hence, our developed RP-HPLC method proved to be an efficient analytical tool for in-vitro and in-vivo quantification of naringenin in PLGA nanoparticles.

\section{Conclusions}

An easy, economical, fast, precise, and robust RP-HPLC method was developed and validated for in-vitro and in-vivo determination of naringenin from 
developed PLGA nanoparticles. Further, this method was used to assess entrapment efficiency, drug release, in-vivo pharmacokinetics (plasma and brain concentration), as well as brain to plasma ratio of naringenin from nanoformulation.

\section{Additional file}

Additional file 1: Section S1 Preparation of Naringenin loaded PLGA nanoparticles. Section S2 Single dose Pharmacokinetic Studies and brainuptake study. Table S1 Brain-to-plasma ratios of NGN-Suspension \& NGNPLGA-NPs. Figure S1 Chromatograms of A) blank brain tissue spiked with naringenin B) blank brain tissue C) blank plasma spiked with naringenin D) blank plasma (DOCX $568 \mathrm{~kb}$ )

\section{Abbreviations}

ANOVA: Analysis of variance; AUC: Area under curve; BBB: Blood-brain barrier; CL: Clearance; CMC: Carboxymethyl cellulose; CPSEA: Committee for the Purpose of Control and Supervision of Experiments on Animals; Ke: Elimination rate constant; LOD: Limit of detection; LOQ: Limit of quantification; MRT: Mean residence time; NCA: Non-compartmental analysis; NGN-PLGA NP: Naringenin loaded poly (lactic-co-glycolic acid) nanoparticles; NMT: Not more than; PDA: Photo diode array; PLGA: Poly (lactic-co-glycolic acid); QC: Quality control; RP-HPLC: Reversed-phase high-performance liquid chromatography; RSD: Relative standard deviation; Rt: Retention time; SD rats: Sprague-Dawley; SEM: Scanning electron microscopy; TEM: Transmission electron microscopy; Vd: Volume of distribution

\section{Acknowledgements}

Not applicable

\section{Funding}

Research grants sanctioned by SERB, Department of Science \& Technology (grant no SB/FT/LS-284/2012), All India Council of Technical Education (1125/RIFD/CAYT/POL-II/2013-14), and University Grants Commission (20-29(12)/ 2012(BSR), New Delhi are gratefully acknowledged. Senior Research Fellowship sanctioned by Indian Council of Medical Research (45/13/2014Nan/BMS), New Delhi is also gratefully acknowledged.

\section{Availability of data and materials}

All data generated or analyzed during this study are included in this published article and its supplementary information files as well as will be available from the corresponding author on reasonable request.

Supplementary information files are available online

\section{Authors' contribution}

AK, JKP, AK, and RB designed and conceptualized the study. RB conducted the experimental work. RB and AK compiled and analyzed the data. R B and AK wrote the manuscript. All authors read and approved the final manuscript.

\section{Competing interest}

The authors declare that they have no competing interests.

\section{Publisher's Note}

Springer Nature remains neutral with regard to jurisdictional claims in published maps and institutional affiliations.

\section{Received: 23 November 2018 Accepted: 6 February 2019}

\section{Published online: 01 March 2019}

\section{References}

Badri W, Miladi K, Robin S, Viennet C, Nazari QA, Agusti G, et al. Polycaprolactone based nanoparticles loaded with indomethacin for anti-inflammatory therapy: from preparation to ex vivo study. Pharm Res. 2017;34(9):1773-83. Available from: https://link.springer.com/content/pdf/10.1007\%2Fs11095-0172166-7.pdf. [cited 2017 Dec 5]
Bhandari R, Paliwal JK, Kuhad A. Naringenin and its nanocarriers as potential phytotherapy for autism spectrum disorders. J Funct Foods. 2018;47:361-75. Available from: https://doi.org/10.1016/j.jff.2018.05.065

Birt DF, Hendrich S, Wang W. Dietary agents in cancer prevention: flavonoids and isoflavonoids. Pharmacol Ther. 2001;90(2-3):157-77. Available from: http:// www.sciencedirect.com/science/article/pii/S0163725801001371. [cited 2016 Mar 22]

Cordenonsi LM, Bromberger NG, Raffin RP, Scherman EE. Simultaneous separation and sensitive detection of naringin and naringenin in nanoparticles by chromatographic method indicating stability and photodegradation kinetics. Biomed Chromatogr. 2016;30(2):155-62. Available from: https://onlinelibrary. wiley.com/doi/full/10.1002/bmc.3531

D'Souza SS, DeLuca PP. Methods to assess in vitro drug release from injectable polymeric particulate systems. Pharm Res. 2006;23(3):460-74. Available from: https://link.springer.com/article/10.1007/s11095-005-9397-8. [cited 2017 Mar 2]

Dalagnol M, De Bernardi LS. Development and validation of a RP-HPLC method to quantify naringenin in lecithin / chitosan Nano- and Microparticle suspensions. Lat Am J Pharm. 2013;32(2):214-9.

Felgines C, Texier O, Morand C, Manach C, Scalbert A, Régerat F, et al. Bioavailability of the flavanone naringenin and its glycosides in rats. Am J Physiol Gastrointest Liver Physiol. 2000;279(6):G1148-54.

Fessi H, Puisieux F, Devissaguet JP, Ammoury N, Benita S. Nanocapsule formation by interfacial polymer deposition following solvent displacement. Int J Pharm. 1989;55(1):R1-4.

Fisher JF, Wheaton T. High-pressure liquid chromatographic method for the resolution and quantitation of naringin and naringenin rutinoside in grapefruit juice. J Agric Food Chem. 1976;24(4):898-0.

Fuhr U, Klittich K, Staib AH. Inhibitory effect of grapefruit juice and its bitter principal, naringenin, on CYP1A2 dependent metabolism of caffeine in man. Br J Clin Pharmacol. 1993;35(4):431-6. Available from: https://www.ncbi.nlm. nih.gov/pmc/articles/PMC1381556/

Gáll Z, Vancea S, Szilágyi T, Gáll O, Kolcsár M. Dose-dependent pharmacokinetics and brain penetration of rufinamide following intravenous and oral administration to rats. Eur J Pharm Sci. 2015;68:106-13. Available from: https://doi.org/10.1016/j.ejps.2014.12.012

Galluzzo P, Ascenzi P, Bulzomi P, Marino M. The nutritional flavanone naringenin triggers antiestrogenic effects by regulating estrogen receptor alphapalmitoylation. Endocrinology. 2008;149(5):2567-75. Available from: http:// www.ncbi.nlm.nih.gov/pubmed/18239068. [cited 2016 May 17]

Guidance for Industry Q2B Validation of Analytical Procedures: Methodology. 1996;20857:301-827. Available from: http://www.fda.gov/cder/guidance/ index.htm. [cited 2016 May 22]

Gupta V, Srivastava M, Maurya R, Sk P, Dwivedi AK. HPLC method development for naringenin and its glucoside in rat serum and their Bioavailibilty studies. J Bioequiv Availab. 2012;S14:010. https://doi.org/10.4172/jbb.S14-010.

Ishii K, Furuta T, Kasuya Y. Determination of naringin and naringenin in human urine by high-performance liquid chromatography utilizing solid-phase extraction. J Chromatogr B Biomed Sci Appl. 1997;704(1-2):299-305. Available from: https://www.ncbi.nlm.nih.gov/pubmed/9518163. [cited 2016 May 19]

Jaenicke L. Buffers for pH and metal ion control. VonD. D. Perrin undB. Dempsey. Chapman and Hall, London 1974. 1. Aufl., VII, 176 S., zahlr. Tab., geb. $£ 3.50$. Angew Chemie. 1975;87(6):211. Available from: http://doi.wiley.com/10.1002/ ange.19750870621. [cited 2019 Jan 13]

Jain A, Jain A, Garg NK, Tyagi RK, Singh B, Katare OP, et al. Surface engineered polymeric nanocarriers mediate the delivery of transferrin-methotrexate conjugates for an improved understanding of brain cancer. Acta Biomater. 2015;24:140-51. Available from: https://doi.org/10.1016/j.actbio.2015.06.027

Ji P, Yu T, Liu Y, Jiang J, Xu J, Zhao Y, et al. Naringenin-loaded solid lipid nanoparticles: preparation, controlled delivery, cellular uptake, and pulmonary pharmacokinetics. Drug Des Devel Ther. 2016;10:911-25.

Khan AW, Kotta S, Ansari SH, Sharma RK, Ali J. Self-nanoemulsifying drug delivery system (SNEDDS) of the poorly water-soluble grapefruit flavonoid Naringenin: design, characterization, in vitro and in vivo evaluation. Drug Deliv. 2015;22(4):552-61. Available from: http://www.tandfonline.com/doi/full/ 10.3109/10717544.2013.878003

Kumar S, Tiku AB. Biochemical and molecular mechanisms of radioprotective effects of naringenin, a phytochemical from citrus fruits. J Agric Food Chem. 2016;64(8):16761685. Available from: https:/pubs.acs.org/doi/abs/10.1021/acs.jafc.5b05067

Kumari A, Yadav SK, Yadav SC. Biodegradable polymeric nanoparticles based drug delivery systems. Colloids Surfaces B Biointerfaces. 2010;75(1):1-18. 
Muthu MS, Rawat MK, Mishra A, Singh S. PLGA nanoparticle formulations of risperidone: preparation and neuropharmacological evaluation. Nanomedicine. 2009;5(3):323-33. Available from: http://www.ncbi.nlm.nih. gov/pubmed/19523427. [cited 2017 Mar 1]

Nahmias Y, Goldwasser J, Casali M, Van Poll D, Wakita T, Chung RT, et al. Apolipoprotein B-dependent hepatitis C virus secretion is inhibited by the grapefruit flavonoid naringenin. Hepatology. 2008;47(5):1437-45.

Natarajan J, Baskaran M, Humtsoe LC, Vadivelan R, Justin A. Enhanced brain targeting efficacy of Olanzapine through solid lipid nanoparticles. Artif Cells Nanomedicine Biotechnol. 2017;45(2):364-71. Available from: https://www. ncbi.nlm.nih.gov/pubmed/27002542. [cited 2018 Mar 5]

Peng HW, Cheng FC, Huang YT, Chen CF, Tsai TH. Determination of naringenin and its glucuronide conjugate in rat plasma and brain tissue by highperformance liquid chromatography. J Chromatogr B Biomed Appl. 1998; 714(2):369-74.

Peter Christoper GV, Vijaya Raghavan C, Siddharth K, Siva Selva Kumar M, Hari Prasad R. Formulation and optimization of coated PLGA_Zidovudine nanoparticles using factorial design and in vitro in vivo evaluations to determine brain targeting efficiency. Saudi Pharm J. 2014;22(2):133-40. Available from: https://doi.org/10.1016/j.jsps.2013.04.002

Ratnam DV, Ankola DD, Bhardwaj V, Sahana DK, MNVR K. Role of antioxidants in prophylaxis and therapy: a pharmaceutical perspective. J Control Release. 2006;113(3):189-207. Available from: https://www.sciencedirect.com/science/ article/pii/S0168365906002057. [cited 2016 May 18]

Raza SS, Khan MM, Ahmad A, Ashafaq M, Islam F, Wagner AP, et al. Neuroprotective effect of naringenin is mediated through suppression of NFj B signaling pathway in experimental stroke. Neuroscience. 2013;230:157-71. Available from: https://doi.org/10.1016/j.neuroscience.2012.10.041

Ribeiro IA, Ribeiro MHL. Naringin and naringenin determination and control in grapefruit juice by a validated HPLC method. Food Control. 2008;19(4):432-8.

Suseela P, Premkumar K, Saraswathy SD. Formulation, characterization and pharmacokinetic evaluation of naringenin- loaded gastroretentive mucoadhesive polymeric nanosystem for oral drug delivery. J Drug Deliv Ther. 2015;5(2):107-14. Available from: http://jddtonline.info/index.php/jddt/ article/view/1091. [cited 2017 Mar 27]

Tiwari SK, Agarwal S, Seth B, Yadav A, Nair S, Bhatnagar P, et al. Curcumin-loaded nanoparticles potently induce adult neurogenesis and reverse cognitive deficits in Alzheimer's disease model via canonical Wnt/ $\beta$-catenin pathway. ACS Nano. 2014;8(1):76-103. Available from: http://pubs.acs.org/doi/10.1021/ nn405077y. [cited 2017 Nov 14]

U.S. Department of Health and Human Services Food and Drug Administration. n.d.. Bioanalytical Method Validation Guidance for Industry; Available from: https://www.fda.gov/downloads/Drugs/Guidance/ucm070107.pdf. [cited 2018 May 13]

USP32-NF27. (2006). General chapters: validation of compendial methods. Available from: http://www.pharmacopeia.cn/v29240/usp29nf24s0_c1225.html

Vallverdu A, Odriozola-serrano I, Oms-oliu G, Lamuela-ravento RM, Elez-mart P, Mart $\mathrm{O}$. Changes in the polyphenol pro fi le of tomato juices processed by pulsed electric fields. J Agric Food Chem. 2012;60:9667-72.

Wu LH, Lin C, Lin HY, Liu YS, Wu CYJ, Tsai CF, et al. Naringenin suppresses neuroinflammatory responses through inducing suppressor of cytokine signaling 3 expression. Mol Neurobiol. 2016;53(2):1080-91.

Xu Q, Hashimoto M, Dang TT, Hoare T, Kohane DS, Whitesides GM, et al. Preparation of monodisperse biodegradable polymer microparticles using a microfluidic flowfocusing device for controlled drug delivery. Small. 2009;13:1575-81. Available from: http://www.ncbi.nlm.nih.gov/pubmed/19296563. [cited 2017 Mar 2]

Xue M, Hu S, Lu Y, Zhang Y, Jiang X, An S, et al. Development of chitosan nanoparticles as drug delivery system for a prototype capsid inhibitor. Int J Pharm. 2015;495(2):771-82. Available from: https://www.sciencedirect.com/ science/article/pii/S037851731530154X. [cited 2017 Dec 5]

Yen F-L, Wu T-H, Lin L-T, Cham T-M, Lin C-C. Naringenin-loaded nanoparticles improve the physicochemical properties and the hepatoprotective effects of naringenin in orally-administered rats with $\mathrm{CCl}(4)$-induced acute liver failure. Pharm Res. 2009;26(4):893-902. Available from: https://www.ncbi.nlm.nih.gov/ pubmed/19034626. [cited 2016 May 18]

Yi L-T, Liu B-B, Li J, Luo L, Liu Q, Geng D, et al. BDNF signaling is necessary for the antidepressant-like effect of naringenin. Prog Neuropsychopharmacol Biol Psychiatry. 2014;48:135-41. Available from: https://www.sciencedirect. com/science/article/pii/S0278584613002182. [cited 2016 May 16]

\section{Submit your manuscript to a SpringerOpen ${ }^{\odot}$ journal and benefit from:}

- Convenient online submission

- Rigorous peer review

- Open access: articles freely available online

High visibility within the field

- Retaining the copyright to your article

Submit your next manuscript at $\boldsymbol{\nabla}$ springeropen.com 